\title{
COMMUNITY ENGAGEMENT: BARRIERS AND DRIVERS IN SOUTH AFRICAN HIGHER EDUCATION
}

\author{
B. J. Johnson \\ Transformation Employment Equity \\ University of the Witwatersrand \\ Johannesburg, South Africa \\ e-mail: bernadette.johnson@wits.ac.za
}

\section{ABSTRACT}

Community engagement professionals experience numerous barriers even though community engagement is the third mission of the university alongside first, teaching and learning, and second, research. Community engagement professionals often refer to community engagement as the "stepchild" of higher education. Yet there are also inter-related successful drivers. This article identifies the barrier-driver duality and makes a case for their systemic interconnectedness, an area that has thus far been underexplored. A prominent barrier for community engagement professionals is that there is a lack of substantive conceptualisation of community engagement, intensified by the contradictory placing of community engagement within community and university structures. Interconnected to such barriers, prominent drivers demonstrate the value of scholarly, reflective practice and to enhance the leadership role of the South African Higher Education Community Engagement Forum, inclusive of the views of pertinent members such as academic leaders, students and communities.

Keywords: community engagement, integrating barriers and drivers, community engagement practitioners,

\section{INTRODUCTION}

Solidarity between universities and communities, it may be assumed, would consolidate community engagement (CE) as a system through which universities could engage with the developmental needs of communities. Even the leading scientific thinking of Nature states: "Why do so many scientists ignore the need of our cities [...] Researchers who benefit from the opportunities in cities should ask what can they give back" (Nature 2010, 883-884). More currently, Goddard, Hazelkorn and Vallance (2016) take up this matter, and invite the societalto-university engagement to invoke the civic spirit of universities. If for the sake of this argument cities may be assumed to be proxies for the communities, it appears that universities are not yet reciprocally engaged with the very communities that give life to their work, a contention also borne out by the ASHE Higher Education Report (2014) which prompted the research problem Specifically, within the very same universities, CE practitioners themselves 
express their frustration at the neglect of $\mathrm{CE}$ even though it is the legislated third mission of universities in South Africa, alongside teaching and learning as the first, and research as the second mission. While practitioners share their understanding of what may be hindering CE, there remains a dearth of literature on a closer identification of barriers and drivers in South African higher education (HE), thus confirming the research problem. Furthermore, barriers and drivers may not be binary as is often conceived, but, more powerfully, systemic and interconnected (Bocken and Geradts 2019). This is also borne out by considerations of studies in a sample of, for instance, three research-intensive countries: in the USA, Weerts and Sandmann (2008) studied challenges and opportunities of CE in research universities, Goddard (2007) explored regional collaboration in the UK, and Kearney (2015) researched challenges of CE in Australia.

Barriers and drivers in a system may be identified by different stakeholders, and may be experienced in different ways, at different levels. Knowing what the barriers and drivers are and that they are interconnected could advance CE professionals' creativity and strategic engagement. In relation to the research problem signalled above, a research gap has been identified by Bellig, Moely and Holland $(2014,274)$ who urge for definitive best practice-based research in this field. This article attends to these gaps, while also drawing data from a larger NRF-funded study on shifting concepts and meanings of community engagement in HE.

Additionally, informed by the findings of the study that spanned three years, this article builds theoretically on the work of Weerts and Sandmann (2008) by offering a framework through which to understand the barriers and drivers of CE in South African HE. Such a framework would be relevant to researchers as well as HE managers and leaders, as it could illuminate the most present barriers and drivers and explain why non-university community experiences are not sufficiently appreciated by the universities themselves.

\section{BARRIERS TO AND DRIVERS OF COMMUNITY ENGAGEMENT GLOBALLY}

Consistent with the literature, barriers are referred to as obstacles or challenges and drivers as facilitators or enablers in the discussion. The definitions of CE differ vastly across different countries and different universities (Lazarus et al. 2008). The diversity of meanings is what Sandmann $(2008,101)$ calls "definitional anarchy" in the USA. In the USA, CE is mainly referred to as "engaged scholarship" and "service learning" (Sandmann 2008); in the UK, it is called "civic engagement" (Goddard and Vallance 2011) and "Solidaridad" in Latin America (Rabin 2014; Tapia 2014). In South Africa, various terms are used, for example "volunteerism”, "service learning" and "engaged scholarship". What is, however, common to all forms of CE is that the university extends itself beyond its internal community to its external non-university 
communities for various purposes and in a variety of different ways.

Barriers and drivers in the non-South African literature have been considered in relation to institutional types (Weerts and Sandmann 2008), levels within a system - whether at interpersonal, institutional or national levels (Weerts and Sandmann 2008) - and the local level in relation to regional innovation systems (Goddard 2007).

Weerts and Sandmann (2008) consider barriers and enablers of CE at research universities in the USA in the context of these universities having adopted a two-way interactive model of engagement, which this study frames as interconnectedness. Previously, institutions conducted their engagement as a one-way interaction with knowledge based on a rational and objective world view distributed from experts in the university to a two-way partnership or collaboration based on a constructive model in which learning happens in the context of addressing societal needs (Weerts and Sandmann 2008, 75-78). The same authors capture the barriers and enablers of a two-way knowledge flow model in the context of research universities at institutional and interpersonal levels. They discuss these levels with reference to inter alia mission, place, epistemology, institutional complexity, boundaries and rewards, academic roles, as well as leadership and culture (Weerts and Sandmann 2008, 98). (Also see Table 2.)

Goddard and Vallance (2011) focus on the role of the "civic" university in regional development. They argue that the university needs to re-establish connectivity by focusing on local socio-economic needs. Their work is echoed by the ASHE Higher Education Report $(2014,48)$ which states that universities are often an anchor institution in communities. In these debates about the civic role of the university, institutional and cultural barriers are expressed through disciplinary and specialised knowledge, which tends to be inward looking, thus causing the university to be disengaged from playing a role in communities. A case study investigation of three city universities' civic leadership development programmes has revealed a number of obstacles and challenges to developing a "civic university" in the UK. A sample is presented in summary form in Table 1.

Table 1: Obstacles and challenges to the civic university in the United Kingdom (Adapted from Goddard and Vallance 2011, 13-14)

\begin{tabular}{|l|l|}
\hline $\begin{array}{l}\text { Obstacles and challenges faced by university } \\
\text { leaders in working with external bodies }\end{array}$ & $\begin{array}{l}\text { Obstacles and challenges faced by civic leaders } \\
\text { working with universities }\end{array}$ \\
\hline $\begin{array}{l}\text { Universities place limits on the number of external } \\
\text { projects in which they can get involved. }\end{array}$ & $\begin{array}{l}\text { There is a gap between the strategic and operational } \\
\text { levels of the university as leaders make decisions, and } \\
\text { this is often not followed up lower down the university. }\end{array}$ \\
\hline $\begin{array}{l}\text { Establishing "civic partnerships" is not seen as being } \\
\text { part of the core business of the university. Thus, not } \\
\text { many people work in this space and the function is } \\
\text { often cross-subsidised from other funding sources, } \\
\text { hence presenting challenges related to financial } \\
\text { sustainability. }\end{array}$ & $\begin{array}{l}\text { As the university community is diverse, civic } \\
\text { organisations find it challenging to get a single view } \\
\text { from the university. }\end{array}$ \\
\hline Given the multitude of organisations, it is challenging & Many civic leaders do not know who to work with in the \\
\hline
\end{tabular}




\begin{tabular}{|c|c|}
\hline $\begin{array}{l}\text { Obstacles and challenges faced by university } \\
\text { leaders in working with external bodies }\end{array}$ & $\begin{array}{l}\text { Obstacles and challenges faced by civic leaders } \\
\text { working with universities }\end{array}$ \\
\hline to know with which organisations to collaborate. & $\begin{array}{l}\text { university structure as the university is vast and there } \\
\text { is not necessarily one point of contact. }\end{array}$ \\
\hline $\begin{array}{l}\text { Universities are not directly in the political sphere and } \\
\text { therefore are challenged in exerting political influence. }\end{array}$ & $\begin{array}{l}\text { People outside the university do not understand the } \\
\text { policies and procedures or the organisational structure } \\
\text { of the university and therefore find it hard to interact } \\
\text { with the university. The language or jargon (for } \\
\text { example "Vice-Chancellor") may not be clearly } \\
\text { understood. }\end{array}$ \\
\hline $\begin{array}{l}\text { Changing political leadership makes building long- } \\
\text { term relationships with the city council challenging. }\end{array}$ & $\begin{array}{l}\text { Business and health services find the universities' } \\
\text { responses to be overly bureaucratic and slow. }\end{array}$ \\
\hline $\begin{array}{l}\text { External organisations, and private and public or third } \\
\text { sectors may have a poor perception of the university } \\
\text { and regard it as being unreliable, inefficient and overly } \\
\text { self-interested. Consequently, organisations are often } \\
\text { not necessarily interested in working with universities } \\
\text { nor may they be aware of the opportunities that there } \\
\text { may exist in working with universities. }\end{array}$ & $\begin{array}{l}\text { Gifted academics are focused on incentives and } \\
\text { targets and this may distract individuals from working } \\
\text { with external organisations. }\end{array}$ \\
\hline
\end{tabular}

Goddard et al. (2016) also discuss the drivers and barriers of universities in the UK in terms of becoming engaged locally to support regional economic development, with special focus on the Newcastle University's journey in the UK. They identify a number of drivers. Firstly, there were changes in the national HE system in the UK through which the role of HE in economic development was recognised and supported by the regional development agencies. Funding for partnerships, research, skills development and knowledge transfer was made available to stimulate partnerships with external private and public entities. Secondly, changes were brought about in government policy, such as the reduction in state funding, which stimulated universities to seek funding from other sources since they could not rely solely on state funding for research and students. Drivers at institutional level included changes in institutional vision and focus through strong institutional leadership, a change in processes, and the creation of structures especially at Pro-Vice-Chancellor's level for research, innovation and engagement. Consistently, here too, Goddard argues that leadership is critical to take the strengths of the universities outward to the external environment.

The international literature tends to focus on barriers and drivers with reference to their country-specific notion of CE and the experience of barriers and drivers in implementation of a shared understanding of CE. In the USA, for example, CE is guided by the Carnegie Classification framework which is operationalised within the university structures of outreach and engagement with senior leadership to facilitate such engagement. South Africa presents a different context.

\section{BARRIERS TO AND DRIVERS OF COMMUNITY ENGAGEMENT IN SOUTH AFRICA}

In South Africa, there is no nationally agreed upon framework to guide the implementation of 
$\mathrm{CE}$ in universities. Yet the White Paper on the Transformation of Higher Education (Department of Higher Education 1997), already in 1997, advocated the imperative to socially engaged and democratised teaching and learning, within the universities' ambit. As noted by Bhagwan $(2017,172)$, this commenced iterative formulations of CE from 1997-2006 to its naming as "scholarship of engagement" (HEQC, CHESP 2006). Speaking to the heart of academia as scholarship, this rooted CE within both teaching and research, and not as a separated mission of universities. Taking this further into a framework, however, has not yet been achieved, despite the recommendation for "a rigorous conceptual framework" Conversely too, the HEQC has only tabled a rudimentary definition of CE (Bhagwan 2017, 172).

Accordingly, Favish and Ngcelwane (2013) surveyed universities to establish what they regard as their barriers and drivers in South Africa. The survey, as cited in a Council on Higher Education report (2016), indicates the following challenges: (i) development of mechanism to evaluate the quality of CE; (ii) lack of funding; (iii) competing priorities in relation to academic workloads; (iv) difficulty in changing mind-sets about the nature of CE in relation to teaching and learning and research; (v) lack of executive leadership support in understanding CE, its mandate and potential.

Dr Jerome Slamat, the first chairperson of the South African Education Community Engagement Forum (SAHECEF), which was launched in 2008, draws from discussions in the SAHECEF Management and Governance Work Group during 2011 and 2012. He argues that, consistent with international literature, institutional-level elements that are interconnected should support engagement. He specifically refers to management support, resources, a $\mathrm{CE}$ policy, an institution register of community-university engagement initiatives, a Senate committee, faculty committees and CE chairpersons, a central CE support service or unit, and recognition of CE.

Barriers and drivers have also been discerned as specific thematic areas. Examples are partnerships (Brown-Luthango 2013; Wood and Zuber-Skerrit 2013), service learning (Erasmus 2007), university education-teacher relations/partnerships in rural schools (Ebersöhn et al. 2015), and university-school CE (Cherrington et al. 2019).

To contribute to the national commitment to $\mathrm{CE}$, this article offers insights into barriers and drivers while recognising that there is no universalised concept of $\mathrm{CE}$ within the different university settings.

\section{METHODOLOGY}

An interpretivist paradigm and qualitative methodology were followed given the focus of the study. Thus, multiple interpretations of reality would be revealed (Schwandt 2003; Scott and 
Morrison 2006; Baxter and Jack 2008). Various qualitative methods, as described below, were used.

Documentary analysis (Bowen 2009) included institutional documents and grey literature shared with me by CE managers and SAHECEF Members, as well as institutional websites.

In addition, a comprehensive search was conducted in the Web of Science Social Science Citation Index and the Emerging Sources Citation Index. There was an overlap between the Web of Science databases and the more subject specialist databases such as ERIC and Education Search Complete. The search was conducted for deepened documentary analysis to cover work published between 2000 and 2019. Other databases that were searched were ERIC, Education Research Complete, Google Scholar for grey literature, and Sabinet Online. Journals that are indexed by Web of Science include the South African Journal of Higher Education, Journal of Student Affairs in Africa, Transformation in Higher Education (Indexed by ERIC and EBSCO), SA Journal of Education (indexed by WOS), Journal of Higher Education Outreach and Engagement (covered by WOS) and the International Journal of Sustainability in Education (WOS).

The research focused on the phenomenon under study and therefore the context of CE has been provided so that context-related meaning is provided. This follows Englander (2019) who indicates that the knowledge claim centres on meaning rather than sample size and strategies. For transparency, the researcher did use purposive sampling of documents, as above. Journaling and self-reflection notes from SAHECEF meetings and conferences were used. For instance, at a recent Gauteng Regional SAHECEF Chapter in November 2019, I presented preliminary findings and facilitated a discussion on what the barriers and drivers may be in SAHECEF regarding university $\mathrm{CE}$ regional collaboration. These methods helped me embrace my researcher-participant role more reflexively. As chairperson of SAHECEF I grappled with my dual role as chair and researcher in gathering data. I found it challenging to be an insider participant as well as a researcher.

However, within these context-bound experiences (Englander 2019), the meaning that emerged is still transferable across contexts, as is evident, for example, in the importance of funding the nature of university leadership, the structure and nature of the university and its relations with communities. Context-bound differences are related to the extent of leadership commitment and the implementation of $\mathrm{CE}$ strategies and practices, noting that the universalised meaning often transcends contexts due to similar experiences.

In-depth interviews were conducted, within context (Englander 2019) with $14 \mathrm{CE}$ practitioners (managers and/or directors) at universities from 2016 to 2019. Three external stakeholders: the Human Sciences Research Council, the Department of Higher Education and 
the Universities of South Africa Forum also took part in the study. Selection was again directed to discern context and was purposive (Englander 2019; Schwandt 2003). Initially, deputy vicechancellors (DVCs) and vice-chancellors (VCs) were identified; however, given their time constraints, the focus became CE practitioners.

The interview questions were open-ended, opting for conversational prompts rather than a formal schedule to gain meaning-rich responses (Englander 2019). The prompts centred on: how $\mathrm{CE}$ evolved in the context of the university; what are regarded as the barriers and drivers; how $\mathrm{CE}$ can be strengthened institutionally and in the national system; and what the role of SAHECEF should be in this context?

I realised during the research process that changes would have taken place at institutions during the time that the data were gathered. "Fees must fall" protests had a significant impact on data gathering as campuses were routinely closed, making access to the universities challenging. For example, one university changed its name and some appointed new VCs. The context of the universities too had changed from a pre-"Fees must fall" period to a post-"Fees must fall" period. Given the evolved context, opportunities for the field work with CE practitioners was, as noted, at SAHECEF 2019 conference as well as Gauteng regional chapter.

Considerable data was generated, given the position of this study in the NRF broader study. I chose to focus on the CE barriers and drivers to strengthening of CE.

Three steps were followed during data analysis: reviewing the pre-coding of the data for meaning, coding cycles and then clustering the data for themes (Saldaña 2016). Because of the length of the interviews, it was challenging to establish preliminary patterns while comparing and organising the data. Interviews had continued for 1 hour 30 minutes or even longer.

Ethically, SAHECEF gave permission for the study to be conducted. All the participants gave informed consented. Trustworthiness criteria (Nowell et al. 2017) were adhered to. This included checking the interview questions with colleagues in SAHECEF and some selected critical stakeholders. The data were also sent to CE practitioners for their member-checking.

\section{FINDINGS}

In the discussion on the findings, interviewees are referred to as Participant 1 (P1) to Participant 10 (P10). Journal reflections are named Journal Reflection 1 (JR1) to Journal Reflection 4 (JR4).

While a central premise of this study is that barriers and drivers are closely inter-connected (see Table 2), the respective barriers and drivers are presented separately for ease of reference. 


\section{BARRIERS TO COMMUNITY ENGAGEMENT}

Various barriers to community engagement were analysed.

\section{FUNDING}

$\mathrm{CE}$ practitioners emphasised the absence of government funding as the prominent barrier. An established CE scholar commented:

“[P]eople are really committed to CE. The biggest barrier is finances. It's not people's willingness, it's not commitment, it's not philosophy, it's not the value system, it's not their ability [...] because you can't grow up in South Africa and work in a university with people from diverse backgrounds and not know that you need to engage" (P1).

Goddard and Vallance (2011) mention that without sustained funding, UK staff involved in CE, considered a non-core activity, are limited with funding derived through cross-subsidy, and therefore, often unsustainable. Notwithstanding this tenet, regional development agencies were established by the UK government to stimulate regional and often private sector economic development with universities funded as knowledge partnerships. In contrast, despite the science and technology strategy for innovation in South Africa, most funding for education and innovation comes mainly from government and not the private sector (MacGregor 2014), as explained below.

In South Africa, state subsidy funding is channelled to teaching and learning, and research. There is also ring-fenced funding such as the University Capacity Development Grant. CE practitioners try to access this funding by showing the integration of $\mathrm{CE}$ in teaching and learning and research. In her conceptual discussion on CE, Bender (2008) considers different approaches to $\mathrm{CE}$, namely the stand-alone silo approach, and the infused approach to $\mathrm{CE}$. Integration strategies could be the latter. Badat $(2013,10)$ asserts that financial scarcity makes CE emotive, as CE is then seen as a luxury, and even if regarded as infused, it is still seen as taking resources away from teaching and learning, and research. However, even if funding were available, the HE system is institutionally and culturally geared towards individual competitiveness as subsidy is allocated for individual outputs and not collaboration.

In universities where the institution's mission and vision integrate $\mathrm{CE}$, funding is allocated inside the university with institutional structures and policies to enable an engaged university (P2). This confirms Bender's (2008) concept of infused funding. Funding remains a critical area of concern. According to Bender (2008, 93-94), the Ministry of Education at the 2006 HEQC/JET Conference on CE stated: "We need to understand that earmarked funding is mainstream funding [...] I must emphasise that earmarked funding in this area (CE) would not 
necessarily come from new funding; it would probably have to come from the same pool ...". As a government official participant also stated: "There are many demands and pressures in HE. Our focus at this stage is not CE especially since universities are doing it anyway" (P3).

Another participant stated that in fact the university itself needs support: "“Fees must fall' damaged the image of the university. The university was seen as a dangerous place. People asked, how can the university solve our problems when it cannot solve their own problems?" (P4). Massification (Altbach 2015) of SA HE has fundamentally transformed institutions that now grapple with attaining excellence alongside inequality, poverty and food insecurity, Covid19 implications experienced by a diverse student population.

\section{THE LACK OF A SHARED UNDERSTANDING OF COMMUNITY ENGAGEMENT}

$\mathrm{CE}$ practitioners agree that defining $\mathrm{CE}$ is challenging as there are different conceptual understandings of $\mathrm{CE}$ in $\mathrm{HE}$. Even though seasoned practitioners are frustrated with this conversation (JR3), it persists. In 2013, the first chairperson of SAHECEF argued that work regarding the conceptualisation of CE needs to continue (Slamat 2013, 156). Given changes in staffing and the emergence of new layers in SAHECEF, these concerns are of on-going interest (JR4). Finding opportunities to reflect critically on shifts in institutional thinking and practices could be strengthened within SAHECEF's or through regional networks of universities.

The lack of a shared understanding is characterised by different words associated with $\mathrm{CE}$ and no common language - and even when the same words are used, different interpretations are evident. Weerts and Sandmann (2008) refer to the epistemological matter of what counts as knowledge: discourses are used to create a privileged flow of knowledge (university-tocommunity). In this instance, different words and concepts are used in different institutions. It may or may not be possible to use them interchangeably, and terminology thus creates different reference points and different notions of what counts as knowledge.

A participant noted that the absence of a common definition is a challenge: "There is no common definition of CE. So, who is a community?" (P7). This is a question which seems to exhaust seasoned CE practitioners (P1, P2, P8). It is also ideologically contested. For example, some universities include industry in their CE programmes. Another question is whether "Community"/"C" should be removed from "Community engagement"/"CE". At some institutions "Community" is not part of the institutional CE discourse. At one university the argument is that the university works with all its publics (P2), while at another it is argued that people assume the focus is poor or impoverished communities or non-governmental type work, so in both instances the "C" in "Community engagement" (CE) is silent with the focus on research, hence engaged scholarship (ES). 
Having a conceptual framework is crucial in shaping practice and attracting resources. As one participant indicated:

"I have shared a lot of my documents but I often say to them: 'If your conceptual framework is not the same as ours you can't use these documents because everything is based on the conceptual framework. The way that you record it, the way that you reward it, is all based on the conceptual framework" (P2).

At some universities the conceptual framework includes the role of the university in regional economic development, at others it is more focused on research than on teaching and learning or vice versa. According to Goddard (2018) and Cooper (2009), the notion of the quadruple helix was introduced to extend engagement to include civil society in addition to industry, government and other universities.

The importance of having a common conceptual understanding of practice is evident where CE practitioners feel misplaced. One of the participants commented:

"I'm very disillusioned because we are placed in advancement, in the unit of Advancement within the Unit of Advancement and the other unit that is with us is Marketing and Branding, Alumni, Fundraising and us [...] the whole landscape is about marketing [...] community engagement is misplaced" (Participant 11).

The consequence of this placement is that $\mathrm{CE}$ units and staff risk being marginalised within the university (P6), which in turn influences funding. Staff also needs to understand how to support engagement (P4). Often in CE, safety is an issue as "[p]eople are scared ... in contexts of violence, crime and gangsterism" (P7).

However, being obsessed with concepts can be distracting from practices and "restrictive" if CE is not understood as able to evolve from a pilot to service learning in an organic or flexible manner (P8). Perhaps conceptual and epistemological questions need to be considered in relation to shifting purposes instead of fixed categories.

\section{NOT EVERYONE IS CONVINCED OF THE NEED FOR COMMUNITY ENGAGEMENT}

SAHECEF has been established to advocate for CE in HE in South Africa. Successful conferences and seminars have been hosted to strengthen CE; however, more opportunities are needed to engage in debates that question and try to define CE.

The VC of the University of the Witwatersrand is not convinced of CE. The University of the Witwatersrand does not have a CE office. The VC argues that with good and excellent 
science, CE happens organically. He argues that academics are engaging through their research, especially through HIV and AIDS research, for example (Habib 2019). According to him, "[t]he big project is how do you use the university as a place where you bring in talented students from marginalised communities and give them a fantastic degree? Because when they get a job, they get social mobility that addresses inequality" (Habib 2019). He argued from an ideological point of view: "We are not a party school [...] When people say we are meant to support Mdantsane or Alexandra and not Sandton, I'd say that's nonsense. Our job is to reflect the plurality of the society" (Habib 2019). This broadly raises questions related to the role of universities; but also when engagement happens, one may ask what is required of the university. Weerts and Sandmann (2008) show that engagement that only speaks to what the university is doing is a one-way form of engagement in which expertise is assumed to reside inside the university with no reciprocity between communities and academics.

In his discussion on academic revolutions, Etzkowitz (2003, 110) points out that innovation or extension takes place only after teaching and learning and the research revolutions have taken place. He cites the Massachusetts Institute of Technology as an example. This suggests that excellent research is required for engagement. It raises the question of whether non-research-intensive universities (universities of technology and historically black universities, in South Africa, for instance) are ready for engagement.

Academics who participate in CE are either post-apartheid activists, current activists, inspired by religious belief, have industry experience, have a social work background and/or largely tend to be women. According to a participant,

“... most of the people who are doing engagement are women. In a group of about 20 academics last year there were only two men. The staffing and promotion committees are mostly men and mostly senior academics who are not opposed to engaged scholarship but do not know, are not exposed to the intricacies of engaged scholarship" (P9).

While critical conversations are needed by those unconvinced of the need for engagement, key issues raised herein are that CE needs to be both conceptually and organisationally placed, with a diverse demographic as part of $\mathrm{CE}$.

\section{PRESSURES ON STAFF: ENGAGEMENT IS A LUXURY}

One of the pressures on South African academics is to attain doctoral qualifications. Consequently, they are not able to commit to community engagement. It has implications as convenors put their projects on hold to finish their qualifications (P8).

Other pressures on staff relate to their availability for capacity building due to teaching 
workloads and the emphasis placed on research. A CE practitioner shared that academics are often not able to attend CE training due to their teaching loads. In contrast, practitioners have found that when they host research retreats even during holidays, academics are more likely to attend (P8). Another participant simply commented that "people are overworked and so engagement becomes a luxury. This needs to be fixed" (P4). Yet another participant stated that when it comes to the question of what academics regard as important to spend their time on, it is about "academic identity" (P6). Weerts and Sandmann (2008) raise a similar idea in relation to the importance of rewards that acknowledge and encourage boundary-spanning roles, namely including community engagement as part of shifting academic identities.

\section{LACK OF IMPLEMENTATION OF COMMUNITY ENGAGEMENT IN THE SYSTEM}

Lack of commitment to CE leads to inconsistent implementation or non-implementation. A participant endorsed this view: "Universities talk about it but don't do it effectively enough. I think the lack of transformation in the university sector is a barrier" (P6).

\section{POWER AND EXPLOITATION OF NON-UNIVERSITY COMMUNITIES}

Unequal power relations between academics within their CEs is another area of concern. As indicated:

\footnotetext{
"There are power issues. Institutions are having more power than the communities, and sometimes our communities' voice out their dissatisfaction because sometimes they feel like we do research and they don't benefit. So, they tend not to welcome institutions because we are known for using them for our students to graduate and to build our careers" (P7).
}

How universities are regarded and how they interact with communities is challenging both to universities and communities. Goddard $(2018,364)$ discusses how this is a civic and university leadership challenge in bridging relations between universities and communities. Opportunities could be created to have discussions about how best to engage and overcome power imbalances and to foster opportunities and systems change for collaboration.

\section{DRIVERS OF COMMUNITY ENGAGEMENT}

Drivers, which are inter-related to barriers, were also analysed.

\section{LEADERSHIP COMMITMENT}

Leadership at all levels needs to demonstrate commitment to CE. This should start with the VC. Participants believe that the "VC is your main engager" (P2), with executive support being 
crucial (P8, P10). What leadership communicates is shaped by the mission and vision of the university and its current institutional type: whether it is a research-intensive university, a historically black university, or a university of technology, and so also the specific relevance or responsiveness of CE in that context. As Goddard and Vallance (2011) argue, place-based leadership may need to be enhanced through capacity-building programmes that bridge civic and university leadership through to the operational levels.

Executive leadership needs to encourage deans to initiate engagement projects with heads of school and heads of department and they should seek to get lecturers involved in teaching and learning and research through engagement flagship projects (P7). In this way, what is understood by CE is partly shaped by those to whom CE offices report (P8). For example, in cases where two DVCs are reported to, it can extend the scope of CE. As one participant stated: "It's really a challenge to get the two DVCs working together because sometimes there is a DVC for research and partnerships and there is a DVC for teaching and learning and it becomes difficult sometimes to strike the balance ..." (P8).

This raises the operational challenge of the infusion model (Bender 2008), which does not require a delineated CE line function. However, if a dedicated DVC is considered for engagement, it would be a concern at some institutions that it is not integrated into the teaching and learning if that is their concept of CE (P7).

Leadership changes, inexperienced leadership and leadership staying for too short a period is a concern for CE professionals as it can result in instability (P2). It is important for leadership to be knowledgeable about $\mathrm{CE}(\mathrm{P} 8)$ as it can be a "tremendous challenge when a new leader is appointed and they do not understand CE" (P1).

To complement institution-level leadership, national-level leadership too needs to be strengthened and should include CE professionals making knowledge contributions to the field of CE and encouraging opportunities to reflect critically on CE. It should also include voices that are critical of CE in conversations with SAHECEF. Refreshing and renewing conversations can also be stimulated by extending the membership of SAHECEF to include students, academics and communities.

\section{THE IMPORTANCE OF MIDDLE MANAGEMENT AND LEADERSHIP}

Linked to leadership as described above, is the need for CE to include all levels of leadership and management, especially middle management. A participant commented:

"One of the challenges for us I think is the middle management layer. I mean there is such a focus on 'are you institutionalising, do you get support for top management?' [...] but now when it comes 
to departmental level, if the HODs are not pushing it or putting in place reporting systems, things slip" (P8).

While leadership commitment at the top is important, having leadership to ensure implementation of CE is equally important. Goddard $(2018,362)$ discusses how strategic decisions by university and civic leadership are not necessarily implemented at the core of the university. Middle managers are often critical in strategic implementation (Huy 2001).

\section{THE VISIBILITY OF COMMUNITY ENGAGEMENT}

Having CE being led through the mission and vision of the university is not enough on its own "to keep engagement visible" (P2). Participants emphasised visibility through seminars, conferences and having the leadership of the university attend to highlight the importance of engagement. Incentive and awards systems also assists in raising the visibility of engagement.

One participant commented, "This includes getting people to see what they are doing as engagement and so changing the thinking through creating space for engagement [...] Draw on people who are naturally drawn to engagement and get them to speak to each other and this then creates momentum" (P4). Authors such as Mantere (2005) have emphasised that identifying champions is an important component of bringing about cultural and institutional change.

\section{HAVING ADEQUATE STRUCTURES DRIVEN BY THE LEADERSHIP}

For $\mathrm{CE}$ to develop and become institutionalised, enabling structures need to be developed. While this means that deans and faculties must recognise and encourage engagement projects (P7), it also requires building institutional structures to involve and convince academics of engagement and to promote engagement. As recorded:

"[Enabling structures include] your vision and mission, it means your structure that you report to, the engagement committees, Senate and your plan. It also includes your strategic goal for engagement, key performance areas for HODs, deans and directors. In this way engagement is integrated into the institution's culture" (P2).

While structures may be established, these may change, as a participant highlighted:

\footnotetext{
"When we set up committees, we had a steering committee for community engagement now they have decided we have too many committees and they have collapsed it into the teaching and learning so it's a subcommittee, you know. It doesn't enjoy the same prominence as it did in the past and that is unfortunate" (P10).
} 


\section{ENABLING POLICIES INCLUDING INTEGRATING WITH FUNDING}

Enabling structures must also be supported by enabling policies that promote or encourage staff to become involved and support CE. Enabling policies include staff promotions and funding policies. A participant commented: "What we also have in our nominations criteria are three legs: teaching and learning, research and community engagement $[\ldots]$ and also in some faculties, some faculties now have distinguished teachers' awards, research awards and CE awards" (P10). Seed funding for CE projects assist in getting academics involved in CE projects and the rewards and incentives denote recognition, which sustains CE in the institution. Weerts and Sandmann $(2008,74)$ recognise these as "engagement motivators".

Table 2 presents the framework that is the applied outcome of this study. The table demonstrates how integrated barriers and drivers are, as they are, in effect, flip sides of the same coin.

Table 2: Barriers to and drivers of community engagement in South African higher education

\begin{tabular}{|c|c|c|c|}
\hline & Theme & Barriers & Drivers \\
\hline \multicolumn{4}{|c|}{ Institutional level } \\
\hline & Sustainable funding & Funding & Institutional seed funding \\
\hline & $\begin{array}{l}\text { Epistemology (What } \\
\text { is the language and } \\
\text { discourse used?) }\end{array}$ & $\begin{array}{l}\text { The lack of a shared language } \\
\text { and discourse for the } \\
\text { understanding of CE }\end{array}$ & $\begin{array}{l}\text { Ongoing critical reflections on } \\
\text { what CE means within the } \\
\text { institutional context. }\end{array}$ \\
\hline & $\begin{array}{l}\text { Mission, vision and } \\
\text { place }\end{array}$ & $\begin{array}{l}\text { Ambiguous location of CE in } \\
\text { strategy and implementation }\end{array}$ & $\begin{array}{l}\text { Top leadership buy in and } \\
\text { strategic location of CE }\end{array}$ \\
\hline & $\begin{array}{l}\text { Nature of academic } \\
\text { work }\end{array}$ & $\begin{array}{l}\text { Pressures on staff } \\
\text { Workload pressures } \\
\text { Qualification completion } \\
\text { pressures }\end{array}$ & $\begin{array}{l}\text { Promoting CE as a field of } \\
\text { scholarship and interest among } \\
\text { academics }\end{array}$ \\
\hline & $\begin{array}{l}\text { Institutional } \\
\text { structures and } \\
\text { practices }\end{array}$ & Misplacement of the CE unit & $\begin{array}{l}\text { Having adequate structures } \\
\text { Visibility of CE creating space } \\
\text { for CE conversations through } \\
\text { hosting colloquiums, seminars } \\
\text { Identifying champions of CE }\end{array}$ \\
\hline & & $\begin{array}{l}\text { Operational requirements } \\
\text { Lack of understanding of } \\
\text { professional services such as } \\
\text { information technology, human } \\
\text { relations, IT, HR a and finance } \\
\text { roles in relation to CE } \\
\text { Safety concerns } \\
\text { Insurance concerns }\end{array}$ & $\begin{array}{l}\text { Engagement of professional } \\
\text { administrative support within the } \\
\text { university on CE } \\
\text { Development of safety } \\
\text { guidelines and insurance } \\
\text { matters related to CE }\end{array}$ \\
\hline & Institutional policies & $\begin{array}{l}\text { The absence of institutional } \\
\text { policies that value and } \\
\text { recognise CE } \\
\text { Unequal power relations } \\
\text { between communities and } \\
\text { universities } \\
\text { Exploitation of communities }\end{array}$ & $\begin{array}{l}\text { Rewards and incentives policies } \\
\text { for CE } \\
\text { Staffing and promotion policy } \\
\text { that recognises CE } \\
\text { Workload policy that includes } \\
\text { CE } \\
\text { Guidelines for working with } \\
\text { communities } \\
\text { Research ethics for CE }\end{array}$ \\
\hline
\end{tabular}




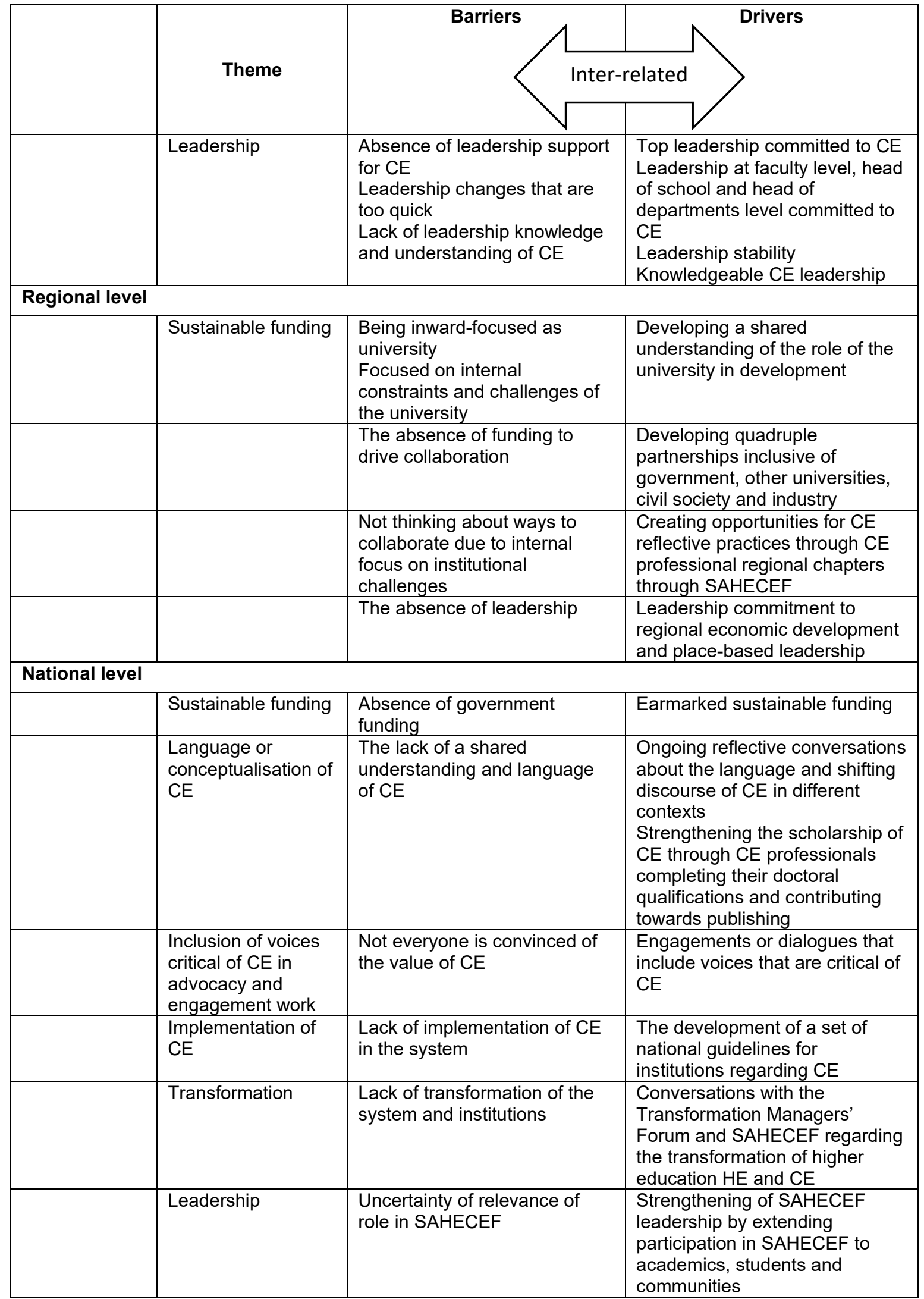

Source: Author

\section{CONCLUSION}

While barriers and drivers are evident and inter-related at institutional and national levels, there are barriers that are within the realm of control of CE practitioners and can be engaged with, 
while others will require leadership interventions at national level. However, for CE to work, the framework must be understood to address barriers through drivers, hence an integrative framework. The barriers within the locus of control of CE practitioners are related to developing the scholarship of $\mathrm{CE}$ through $\mathrm{CE}$ practitioners completing their doctoral qualifications. We need also to engage critically with shifting meanings, language and focus of $\mathrm{CE}$, as well as with voices critical of CE. Through such engagements, the epistemologies of CE can become increasingly refined and sophisticated but ample opportunities need to be developed through national events underpinned by strengthened regional chapters. Funding and implementation of $\mathrm{CE}$ are issues of institutional missions and visions which are spearheaded by university leadership. CE practitioners need to find ways of engaging with VCs and leadership selection processes - perhaps through transformation strategies. Future research needs to explore specific institutional contexts, stakeholder engagement and the value of interpersonal relations in building practices of equality, democracy and reciprocity. CE cannot not simply be regarded as a silo and so be marginalised within the university. It is a powerful transformative force and should be recognised as such.

\section{ACKNOWLEDGEMENT}

I would like to thank SAHECEF for supporting me in undertaking this study, the University of the Witwatersrand for creating space for me to do this work and write the article, and the NRF for its patience and support during my transitioning from executive management into academia.

\section{REFERENCES}

Altbach, Philip. G. 2015. Massification and the global knowledge economy: The continuing contradiction. In Education, I. H. IHE at Twenty Two Decades of News and Analysis, 4-4. http://ejournals.bc.edu/ ojs/index.php/ihe/article/view/6126/5365

ASHE Higher Education Report. 2014. Community as place. The concept of community: Readings with interpretations: 47-48. John Wiley \& Sons, Inc. https://search.ebscohost.com/login.aspx?direct= true $\& \mathrm{db}=$ eue $\& \mathrm{AN}=95779690 \&$ site $=$ eds-live $\&$ scope $=$ site.

Badat, Saleem. 2013. Eleven theses on CE at universities, the social responsibility of universities: Community and civic engagement - context and big picture. The 4th International Exhibition and Conference on Higher Education (4-IECHE), Riyadh, Saudi Arabia, 16-19 April 2013.

Baxter, Pamela and Susan Jack. 2008 Qualitative case study methodology: Study design and implementation for novice researchers. The Qualitative Report 13(4): 544-559.

Bender, Gerda. 2008. Exploring conceptual models for community engagement at higher education institutions in South Africa: Conversation. Perspectives in Education 26(1): 81-95.

Bellig, Shelley, Barbara E. Moely and Barbara A. Holland. 2009. Research informing practice: Developing practice standards and guidelines for improving service learning and community engagement. In Creating our identities in service-learning and community engagement. Partnerships: A Journal of Service-Learning and Civic Engagement (Vol. 0), ed. Barbara A. Holland, Shelley Bellig and Barbara E. Moely. https://doi.org/ 10.7253/partj.v0i0.435

Bhagwan, P. R. 2017. Towards a conceptual understanding of community engagement in higher education in South Africa. Perspectives in Education 35(1): 171-186. https://doi.org/ 10.18820/2519593x/pie.v35i1.13 
Bocken, Nancy M. P. and Thijs H. J. Geradts. 2019. Barriers and drivers to sustainable business model innovation: Organization design and dynamic capabilities. Long Range Planning. (in press). 101950. https://doi.org/ 10.1016/j.lrp.2019.101950

Bowen, Glenn A. 2009. Document analysis as a qualitative research method. Qualitative Research Journal 9(2): 27-40. https://doi.org/10.3316/QRJ0902027

Brown-Luthango, Mercy. 2013. Community-university engagement: The Philippi CityLab in Cape Town and the challenge of collaboration across boundaries. Higher Education 65(3): 309-24. www.jstor.org/ stable/23351699

Cherrington, Avivit M., Eileen Scheckle, Mathabo Khau, Naydene de Lange and A. du Plessis. 2019. What does it mean to be an "engaged university"? Reflections from a university and school-community engagement project. Education, Citizenship and Social Justice 14(2): 165-178. https://doi.org/10.1177\% 2F1746197918779945

Cooper, David. 2009. University-civil society (U-CS) research relationships: The importance of a "fourth helix" alongside the "triple helix" of university-industry-government (UIG) relations. South African Review of Sociology 40(2): 153-180 https://doi.org/10.1080/ 21528586.2009.10425106

Council on Higher Education. 2016. South African higher education reviewed: Two decades of democracy. Pretoria, South Africa: Council on Higher Education.

De Lange, George. 2012. Developing a university-community engagement conceptual framework and typology A case study of a South African comprehensive university. Africa Insight 42(2): 94-111. https://hdl.handle.net/10520/EJC129883

Department of Higher Education. 1997. White Paper 3: A programme for the Transformation of Higher Education. Government Gazette No 1820, 15 August. Pretoria: Government Printers

Ebersöhn, Liesel, Tilda Loots, Irma Eloff and Ronél Ferreira. 2015. Taking note of obstacles research partners negotiate in long-term higher education community engagement partnerships. Teaching and Teacher Education 45: 59-72. https://doi.org/10.1016/j. tate.2014.09.003

Erasmus, Mabel. 2007. Supporting academic staff as champions of service learning. Education and Change 11(3), Special Issue: CSL. http://doi: 10.1080/16823200709487183

Englander, Magnus. 2019. General knowledge claims in qualitative research. Humanistic Psychologist 47(1): 114. https://doi.org/10.1037/hum0000107

Etzkowitz, Henry. 2003. Innovation in innovation: The triple helix of university-industry-government relations. Social science information 42(3): 293-337.

Favish, Judy and Sonwabo Ngcelwane. 2013. Survey of community engagement practices at universities. (Unpublished background survey for task team).

Goddard, John. 2007. The engagement of higher education institutions in regional development: An overview of the opportunities and challenges. Paper presented at the OECD/IMHE International Conference 19-21 September 2007, Valencia, Spain.

Goddard, John. 2018. The civic university and the city. In Geographies of the University, 355-373. Springer, Cham

Goddard, John, Ellen Hazelkorn and Paul Vallance. (Eds.). 2016. The civic university: The policy and leadership challenges. Edward Elgar Publishing.

Goddard, John and Paul Vallance. 2011. The civic university and the leadership of place. Centre for Urban and Regional Development Studies (CURDS). Newcastle UK: Newcastle University.

Habib, Adam. 2019. Our job is to reflect the plurality of the society. Presentation at University of South Africa Forum (USAF) Conference: Re-inventing South Africa's Universities of the Future. In Daily Higher Education News on-line (DHEN), 19 November 2019. https:/www.newssite.co.za/usaf/universitysociety.html

HEQC, CHESP see Higher Education Quality Committee/Community Higher Education Service Partnerships.

Higher Education Quality Committee/Community Higher Education Service Partnerships. 2006. Community engagement in higher education. Pretoria. Council on Higher Education.

Huy, Quy N. 2001. In praise of middle managers. Harvard Business Review 79(8): 72-79.

Kearney, Judith. 2015. Challenges for community engagement: An Australian perspective. Educational Research for Social Change 4(1): 26-39.

Lazarus, Josef, Mabel Erasmus, Denver Hendricks, Joyce Nduna and Jerome Slamat. 2008. Embedding 
community engagement in South African higher education. Education, Citizenship and Social Justice 3(1): 57-83. https://doi.org/10.1177/1746197907086719

Mantere, Suku. 2005. Strategic practices as enablers and disablers of championing activity. Strategic Organization 3(2): 157-184. https://doi.org/10.1177/1476127005052208

MacGregor, Karen. 27 April 2014. Higher Education in the $20^{\text {th }}$ year of democracy. In University World News. www.universityworldnews.com/article.php?story $=20140425131554856$

Nature 467. 2010. Editorials: 883-884. https://doi.org/10.1038/467883b

Nowell, Lorelli S., Jill M. Norris, Deborah E. White and Nancy J. Moules. 2017. Thematic analysis: Striving to meet the trustworthiness criteria. International Journal of Qualitative Methods 16(1): 1609406917733847.

Rabin, Lisa 2014. Service-learning/Aprendizaje-servicio as a global practice in Spanish. The Routledge handbook of Hispanic applied linguistics, 168-183. Oxon and New York. Routledge.

Saldaña, Johnny. 2016. The coding manual for qualitative researchers. $3^{\text {rd }}$ Edition. Los Angeles, CA: Sage.

Sandmann, Lorilee R. 2008. Conceptualization of the scholarship of engagement in higher education: A strategic review, 1996-2006. Journal of Higher Education Outreach and Engagement: 91-104.

Schwandt, Thomas A. 2003. Three epistemological stances for qualitative inquiry: Interpretivism, hermeneutics, and social constructionism. In The landscape of qualitative research, ed. N. Denzin and Y. Lincoln, 292331. Thousand Oaks, CA: Sage.

Scott, David and Marlene Morrison. 2006. Key ideas in educational research. A\&C Black. London and New York. The Continuum International Publishing Group.

Slamat, Jerome. 2013. Inside View IV.2.1 Community-university engagement in South Africa, Higher Education in the World 5: The Global University Network for Innovation, 152-156. http://www.guninetwork.org/ files/inside view iv.2.1 1.pdf

Tapia, Maria Nieves. 2014. PowerPoint presentation: "University Engagement and academic excellence: A view from the Global South", 11-13 June 2014. Round table discussion Rhodes University, Grahamstown, South Africa.

Weerts, David J. and Lorilee R. Sandmann. 2008. Building a two-way street: Challenges and opportunities for community engagement at research universities. The Review of Higher Education 32(1): 73-106.

Wood, Lesley and Ortrun Zuber-Skerrit. 2013. PALAR as a methodology for community engagement by faculties of education. South African Journal of Education 33(4): 1-15. https://doi: 10.15700/201412171322 